\title{
ACTION OF BLEOMYCIN ON THE BACTERIOPHAGE T7 INFECTION
}

\author{
Kazuo Shishido, Atsuko Watarai, Sachio Naito and Tadahiko Ando \\ Microbiology Laboratory, The Institute of Physical and Chemical \\ Research, Wako-shi, Saitama 351, Japan \\ (Received for publication March 13, 1975)
}

\begin{abstract}
A decrease in production of bacteriophage $\mathrm{T} 7$ was observed in bleomycin-treated Escherichia coli B cells. Bleomycin was found to shorten the eclipse in phage growth. A T7 early gene product, the T7-specific RNA polymerase which catalyzes the transcription of late gene appeared more rapidly in the bleomycin-treated cells than in the non-treated cells. The rate of phage adsorption increased to some extent in drug-treated cells. A possible mechanism to explain the mode of action of bleomycin is discussed.
\end{abstract}

Bleomycin, a water-soluble basic glycopeptide antibiotic, produced by Streptomyces verticillus exhibits antitumor and antibacterial activity. ${ }^{1)}$ This drug has been shown to cause the fragmentation of DNA both in vivo and in vitro. The latter reaction is strongly stimulated by a reducing agent such as $\beta$-mercaptoethanol. ${ }^{2 \sim 5)}$ Bleomycin has been shown to inhibit DNA synthesis in growing cells of E. coli, EHrLICH carcinoma and HeLa cells. ${ }^{6}$ ) In addition, it has been reported by YAMAKI et al. ${ }^{7}$ that bleomycin stimulates breakdown of DNA by a DNase present in the crude extract of $E$. coli B cells and the digestion of salmon sperm DNA by pancreatic DNase is also stimulated by the antibiotic.

Recently, it has been reported by HAIDLE et al. ${ }^{8)}$ that bleomycin causes rapid induction of both $\lambda$ bacteriophage in E. coli $\mathrm{K} 12(\lambda)$ and the defective bacteriophage PBSH in Bacillus subtilis 168. These phage-inducing properties resemble those of an alkylating agent. In this communication, we wish to present studies on the effect of bleomycin on the $\mathrm{T} 7$ infection.

\section{Materials and Methods}

Bleomycin (Lot 7-52G81G82As; DM- $\mathrm{A}_{2}(0.6 \%), \mathrm{A}_{2}(67.9 \%), \mathrm{B}_{2}(30.3 \%), \mathrm{A}_{5}(1.2 \%)$, copper $(<0.01 \%)$ ) prepared by Nihon Kayaku Co., Tokyo, was generously supplied by Dr. Y. OKAMI of the Institute of Microbial Chemistry, Tokyo. The antibiotic was dissolved in water and stored at $-20^{\circ} \mathrm{C}$.

E. coli $\mathrm{B}$ was grown at $37^{\circ} \mathrm{C}$ with aeration in the following M9-based medium: $\mathrm{Na}_{2} \mathrm{HPO}_{4}$ $5.8 \mathrm{~g}, \mathrm{KH}_{2} \mathrm{PO}_{4} 3.0 \mathrm{~g}, \mathrm{NaCl} 0.5 \mathrm{~g}, \mathrm{NH}_{4} \mathrm{Cl} 1.0 \mathrm{~g}, \mathrm{CaCl}_{2} 11.1 \mathrm{mg}, \mathrm{MgSO}_{4} 250 \mathrm{mg}$, glucose $5.0 \mathrm{~g}$, Casamino acid $2.5 \mathrm{~g}$ per liter. Phage $\mathrm{T} 7$ infection was carried out as follows: An overnight culture of $E$. coli $\mathrm{B}$ cells was diluted to $\mathrm{A}_{680 \mathrm{~nm}}$ of 0.1 and shaken under the conditions described above. At $\mathrm{A}_{880 \mathrm{~nm}}$ of 0.2 , equivalent to approximately $2 \times 10^{8} \mathrm{cells} / \mathrm{ml}$, phage was added to give a multiplicity of 0.3 and the culture shaken for the indicated periods. Bleomycin was added in all experiments at the time of dilution of the overnight culture and was continuously present during the cultivation. An assay of the plaque forming units was carried out by the double layer method using enriched HersheY's nutrient agar. ${ }^{9)}$ E. coli $\mathrm{B}$ was used as the indicator strain. E. coli B and phage T7 were gifts from J. TomizawA of the National Institutes of Health, U.S.A.

The enzyme assay for T7-specific RNA polymerase ${ }^{10)}$ present in the crude extract of the phage-infected cells was done as follows: All operations for the preparation of the crude 
extracts were carried out at $0 \sim 4^{\circ} \mathrm{C}$. Aliquots $(300 \mathrm{ml})$ of the phage-infected culture were taken at the indicated times and chilled rapidly by pouring the solution onto ice at $-15^{\circ} \mathrm{C}$. The infected cells were harvested by centrifugation for 30 minutes at $15,000 \mathrm{rev} . / \mathrm{min}$, were suspended in $2 \mathrm{ml}$ of $0.05 \mathrm{M}$ Tris- $\mathrm{HCl}, \mathrm{pH} 8.0,0.01 \mathrm{M} \mathrm{MgCl}_{2}, 0.1 \mathrm{~mm}$ dithiothreitol and $5 \%$ glycerol, and were disrupted by sonic vibration for 3 minutes at 20 kilocycles using a Tomy Seiko ultrasonic disruptor (Model UR-200P). The extracts were centrifuged for 30 minutes at $20,000 \mathrm{rev} / \mathrm{min}$ and the supernatant fluid was assayed for T7-specific RNA polymerase activity. As described previously, ${ }^{11,12)} 0.02 \mathrm{ml}$ of the cell extracts was added to the reaction mixture containing, in a volume of $0.25 \mathrm{ml}, 10 \mu$ moles Tris- $\mathrm{HCl}, \mathrm{pH} 8.0,5 \mu$ moles $\mathrm{MgCl}_{2}, 10 \mu$ moles $\mathrm{KCl}, 1 \mu$ mole $\beta$ mercaptoethanol, $10 \mu \mathrm{g}$ rifampicin (Mann Research Lab.), $5 \mu \mathrm{g}$ T7 DNA and $100 \mathrm{~m} \mu \mathrm{moles}$ each of four ribonucleoside triphosphates $\left(\left({ }^{3} \mathrm{H}\right)\right.$ labeled GTP $3 \times 10^{6} \mathrm{cpm} / \mu$ mole was used as the radioactive marker). After incubation at $37^{\circ} \mathrm{C}$ for 30 minutes, the reaction was terminated by addition of $1.0 \mathrm{ml}$ of $10 \%$ ice-cold trichloroacetic acid. Radioactivity of the acid-insoluble fraction was measured.

\section{Results}

Effect of Bleomycin on the Growth of E. coli

Bleomycin was observed to inhibit the growth of $E$. coli $\mathrm{B}$ in accordance with previous reports by other investigators. ${ }^{6}{ }^{13)}$ It was significantly inhibitory at concentrations higher than $10 \mu \mathrm{g} / \mathrm{ml}$ (Fig. 1). In the culture containing $5 \mu \mathrm{g} / \mathrm{ml}$ bleomycin, the growth rate until the cell density reached $\mathrm{A}_{680 \mathrm{~nm}}$ of 0.2 was not significantly reduced as compared with the control.

\section{Effects of Bleomycin on the Phage Production}

Fig. 2 shows the effect of bleomycin on the production of T7 phage. It was found that

Fig. 1. Effect of bleomycin on the growth of E. coli $\mathrm{B}$

To $5 \mathrm{ml}$ of fresh M9-based medium shown in Materials and Methods was added an overnight culture of bacteria to give a $A_{680 n m}$ of 0.1 and the indicated amounts of bleomycin. The cultures were grown at $37^{\circ} \mathrm{C}$ with aeration. $\mathbf{A}_{860 \mathrm{~nm}}$ of culture tube was measured.

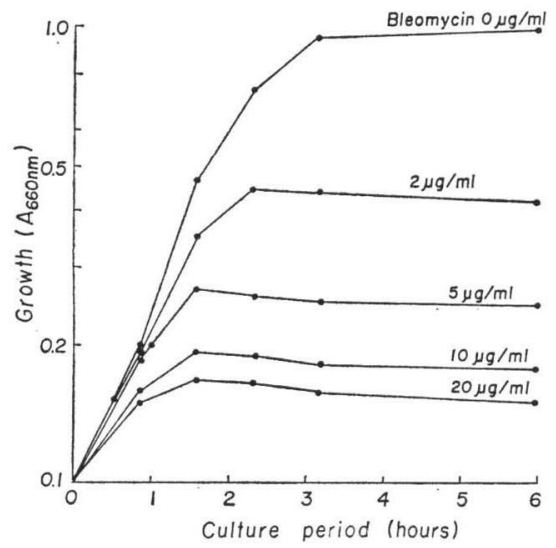

Fig. 2. Effects of bleomycin on the yield of phage $\mathrm{T} 7$ production

The phage production in the presence of the indicated amounts of bleomycin was studied as described in Materials and Methods. Five ml of the infected cultures were shaken at $37^{\circ} \mathrm{C}$ for 60 minutes and, after addition of chloroform and appropriate dilution, the plaque forming units in the culture were assayed. The vertical line shows percentage of production relative to control.

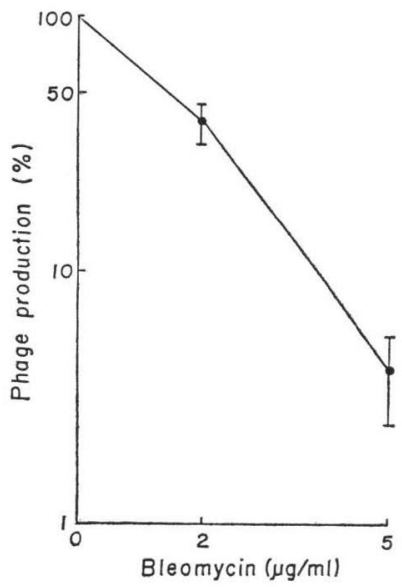


the yield was reduced significantly by the drug under these conditions, inactivation of free phage particles by the drug was not observed. At a concentration of $5 \mu \mathrm{g} / \mathrm{ml}$, the yield was reduced to $1 / 20 \sim 1 / 40$ of the control. This result is expected from the evidence that a drug which induces strand scission of DNA inhibits macromolecule syntheses in E. coli. ${ }^{6}{ }^{6}$

Next, we studied the time course of the infective center count after addition of phage to the culture (Fig. 3). The infective centers were assayed by treatment of the culture with chloroform. The experiment was carried out in the presence of $5 \mu \mathrm{g} / \mathrm{ml}$ of bleomycin. With bleomycin-treated $E$. coli B cells, the infective centers decreased rapidly for $0 \sim 4$ minutes and increased at 6 minutes. With non-treated $E$. coli $\mathrm{B}$ cells, the infective center count decreased for $0 \sim 6$ minutes and a rapid increase of the centers was observed at 8 minutes. These results indicate that new phage particles appear more rapidly in the bleomycin-treated cells than in the non-treated cells. In order to confirm this, we carried out the experiments indicated below.

Fig. 3. Effect of bleomycin on the phage T7 infection

Five $\mathrm{ml}$ of phage-infected culture in the presence or absence of $5 \mu \mathrm{g} / \mathrm{ml}$ of bleomycin was shaken at $37^{\circ} \mathrm{C}$. Aliquots $(0.2 \mathrm{ml})$ of the infected culture were taken at the indicated periods and the infective centers in the cultures were assayed after addition of chloroform. The vertical line shows the number of infective centers relative to that at 0 minute.

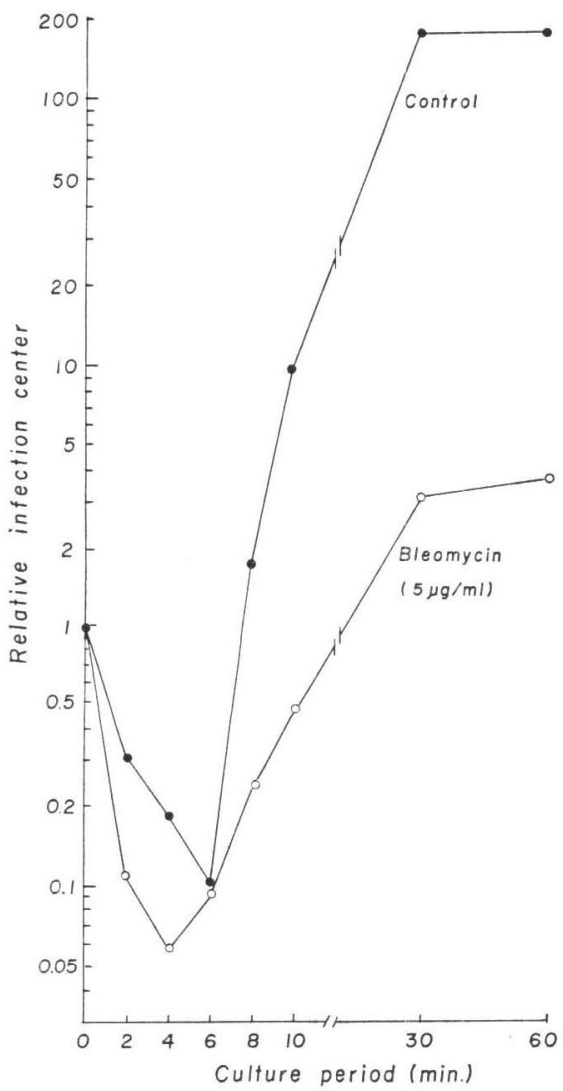

Effect of Bleomycin on the Synthesis of T7-Specific RNA Polymerase

T7-specific RNA polymerase is the product of $\mathrm{T} 7$ gene 1 and physically and biochemically distinct from the host cell RNA polymerase. ${ }^{10,14)}$ T7 RNA polymerase is synthesized by the host cell RNA polymerase and catalyzes the transcription of $\mathrm{T} 7$ late gene. Fig. 4 shows the time course of the synthesis of the T7 RNA polymerase after phage infection. As shown in the figure, the production of $\mathrm{T} 7$ polymerase was more rapid in the

Fig. 4. Effect of bleomycin on the synthesis of T7-specific RNA polymerase

The experiment was carried out in the presence or absence of $5 \mu \mathrm{g} / \mathrm{ml}$ of bleomycin. Aliquots $(300 \mathrm{ml})$ of phage-infected culture were taken at the indicated times and the activity of the T7-specific RNA polymerase in the crude extract of infected cells was assayed as described in Materials and Methods.

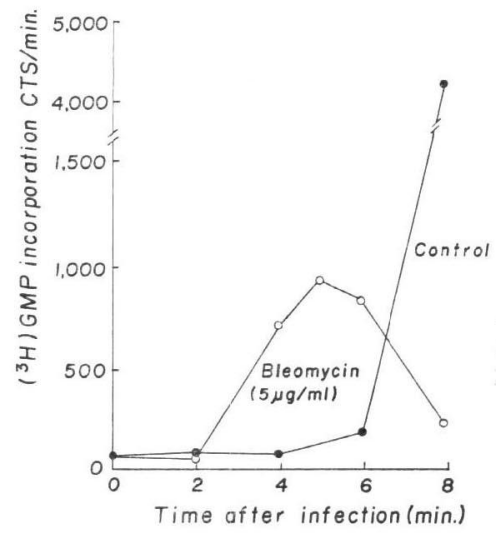


bleomycin $(5 \mu \mathrm{g} / \mathrm{ml})$-treated cells than in the non-treated cells though the extent of production was low compared with the non-treated cells. These results agree with those presented in Fig. 3.

The experiments shown in Table 1 were carried out to show that $\left({ }^{3} \mathrm{H}\right)$ GMP incorporation using the crude extract of $\mathrm{T} 7$-infected cells really reflects the activity of the $\mathrm{T} 7$ polymerase. Infected cells harvested at 8 minutes after phage infection in the absence of bleomycin were used for RNA synthesis in this experiment. We added rifampicin, an inhibitor of E. coli RNA polymerase to the RNA synthesizing system as described in Materials and Methods. Table 1 indicates that the effective incorporation of $\left({ }^{3} \mathrm{H}\right) \mathrm{GMP}$ occured only when using T7 DNA as template. It is known that $\mathrm{T} 7$ polymerase is active only with T7 DNA and is ineffective with T4 DNA or poly dAT. ${ }^{10,14)}$

Table 1. RNA synthesis by the crude extract of the infected cells on T7 and T4 DNAs and poly dAT.

The crude extract was prepared from the infected cells harvested at 8 minutes after phage infection in the absence of bleomycin. The experiment was carried out as described in Materials and Methods except that the same amount of T4 DNA or poly dAT were used in place of T7 DNA.

\begin{tabular}{c|c}
\hline Sort of DNA & $\begin{array}{c}\text { Incorporation of }\left({ }^{3} \mathrm{H}\right) \mathrm{GMP} \text { into } \\
\text { RNA fraction, cts/min }\end{array}$ \\
\cline { 1 - 2 } T7 & 4,207 \\
Note & 60 \\
T4 & 75 \\
Poly dAT & 68 \\
\hline
\end{tabular}

Effect of Bleomycin on the Adsorption of Phage

We tested the effect of bleomycin on the adsorption of phage (Fig. 5). The assay of plaque-forming units was carried out in the presence of $\mathrm{KCN}$ which is known to inhibit the growth of phage during the time of adsorption. The figure shows that the rate of adsorption increased in the bleomycin $(5 \mu \mathrm{g} / \mathrm{ml})$ treated cells though the extent of increase was not great. This observation agrees with that shown in Fig. 3.

\section{Discussion}

Biologically, it is very interesting that phage gene expression and production of new phage particles are more rapid in the bleomycin-treated cells though the yield decreases significantly.

One of several possible mechanisms which would explain these results is as follows: Bleomycin acts through the cell wall on the membrane in the same way as colicin E2 and the alteration of the cell membrane induced by the antibiotic causes an increase in the rate of phage adsorption (see Figs. 3 and 5). It has been shown by other investigators ${ }^{15,18)}$ that the antibiotic appears to act on the cell wall and membrane to induce the release of membrane- 
associated DNA and degradation of the DNA in both bacteria and mammalian cell. However, the increase in the rate of adsorption is not significant.

The other possible mechanism seems to be the stimulatory effect of bleomycin on the destruction of host cell control. It is a truism to say that after infection of $E$. coli with phage such as T7 or T4, the normal host cell control must be removed and the synthesis of host cell component must be halted. The mechanism by which this takes place involves a DNase present in the uninfected cells and/or induced by the phage infection. ${ }^{17)}$ The rapid destruction of the host DNA removes the governing control mechanism in the cell, and products of breakdown are then used for the synthesis of the phage-specific DNA. It has been reported that bleomycin stimulates the breakdown of DNA by a DNase. ${ }^{7)}$ Studies along this line are in progress.

\section{Acknowledgements}

This work was supported by a grant for the studies on "Life Sciences" at the Institute of Physical and Chemical Research and in part by a grant to Prof. Yonosuke Ikeda, The University of Tokyo, from the Ministry of Education of Japan. The authors are indebted to Dr. Y. OKamr of the Institute of Microbial Chemistry, Tokyo, for a generous gift of bleomycin.

\section{References}

1) Ishizuka, M.; H. TAKayama, T. TAKeuchi \& H. Umezawa: Activity and toxicity of bleomycin. J. Antibiotics, Ser. A 20: 15 24, 1967

2) Suzuki, H.; K. Nagai, H. Yamaki, N. TANaka \& H. Umezawa: On the mechanism of action of bleomycin. Scission of DNA strands in vitro and in vivo. J. Antibiotics 22: 446 448, 1969

3) Suzuki, H.; K. Nagai, E. Akutsu, H. Yamaki, N. Tanaka \& H. Umezawa: On the mechanism of action of bleomycin. Strand scission of DNA caused by bleomycin and its binding to DNA in vitro. J. Antibiotics 23: 473 480, 1970

4) NAGal, K.; H. Yamaki, H. SuzUKi, N. TANAKA \& H. Umezawa: The combined effects of bleomycin and sulfhydryl compounds on the thermal denaturation of DNA. Biochim. Biophys. Acta 179: 165 171, 1969

5) Nagai, K.; H. Suzuki, N. Tanaka \& H. Umezawa: Decrease of melting temperature and single strand scission of DNA by bleomycin in the presence of hydrogen peroxide. J. Antibiotics 22: $624 \sim 628,1969$

6) Suzuki, H.; K. Nagai, H. Yamaki, N. Tanaka \& H. Umezawa: Mechanism of action of bleomycin. Studies with the growing culture of bacterial and tumor cells. J. Antibiotics Ser. A 21: $379 \sim 386,1968$

7) Yamaki, H.; H. Suzuki, K. Nagai, N. Tanaka \& H. Umezawa: Effects of bleomycin $\mathbf{A}_{2}$ on deoxyribonuclease, DNA polymerase and ligase actions. J. Antibiotic 24: 178 184, 1971

8) Haidle, C. W.; K. K. Weiss \& M. L. MACE, Jr.: Induction of bacteriophage by bleomycin. Biochem. Biophys. Res. Comm. 48: 1179 1184, 1972

9) Adams, M. H.: Bacteriophages, p 27, Interscience Publishers, Inc., New York, 1959

10) Chamberlin, M.; J. McGrath \& L. Wakell: New RNA polymerase from Escherichia coli infected with bacteriophage T7. Nature 228: 227 231, 1970

11) Shishido, K.: Selection by T7 RNA polymerase of T7 DNA as the template for RNA synthesis. Biochim. Biophys. Acta 312: 708 715, 1973

12) Shishido, K.: Differential inhibition of transcriptions catalyzed by T7-specific and Escherichia coli RNA polymerases by bleomycin. J. Antibiotics 26: 501 505, 1973

13) Onishi, T.; K. Shimada \& Y. TAKAGI: Effects of bleomycin on Escherichia coli strains with various sensitivities to radiations. Biochim. Biophys. Acta 312: 248 258, 1973

14) Chamberlin, M. \& J. McGrath: Characterization of a T7-specific RNA polymerase isolated from E. coli infected with T7 phage. Cold Spring Harbor Symp. Quant. Biol. 35: 259 262, 1970

15) Reiter, H.; M. Milewskiy \& P. Kelley: Mode of action of phleomycin on Bacillus subtilis. J. Bact. 111: 586 592, 1972

16) MiYAKi, M.; T. KitAyama \& T. ONo: Breakage of DNA-membrane complex by bleomycin. J. Antibiotics 27: 647 655, 1974

17) Oleson, A. E. \& J. Koerner: A deoxyribonuclease induced by infection with bacteriophage T2. J. Biol. Chem. 239: 2935 2943, 1964 